\title{
SYNERGISTIC USE OF REMOTE SENSING, GIS AND HYDROLOGICAL MODELS FOR STUDY OF AUGUST 2018 KERALA FLOODS
}

\author{
P. K. Thakur ${ }^{1 *}$, R. Ranjan ${ }^{1,2}$, S. Singh ${ }^{1,3}$, P.R Dhote ${ }^{1}$, V. Sharma ${ }^{1}$, V. Srivastav ${ }^{1}$, M. Dhasmana ${ }^{1}$, S. P.Aggarwal ${ }^{1}$, P. Chauhan ${ }^{1}$, B.R. \\ Nikam ${ }^{1}$, V. Garg ${ }^{1}$ and A. Chouksey ${ }^{1}$
}

\author{
${ }^{1}$ Indian Institute of Remote Sensing, ISRO, 248001, 4-Kalidas Road, Dehradun, Uttarakhand, India - (praveen, pdh, spa, \\ bhaskarnikam, arpit, prakash)@iirs.gov.in; vishal.iirs@gmail.com; vaibhav.iirs@outlook.com; manishdhasmana49@gmail.com \\ 1,2 Indian Institute of Technology (IIT) Delhi, India, cez198241@civil.iitd.ac.in \\ ${ }^{1,3}$ Indian Institute of Technology (IIT) Roorkee, India, sachin.iirs@gmail.com
}

\section{Commission III, ICWG III/IVa}

KEY WORDS: Remote Sensing, Kerala, Flood, Hydrological and hydrodynamic modelling, SAR, GEE

\begin{abstract}
:
Remote sensing and hydrological models are one of the foremost tools for rapid and comprehensive study of flood hazards and disasters in any parts of the world. Current study is focused on severe 2018 Kerala flood, and is done using various remote sensing data, geospatial tools and combination of hydrological/hydrodynamic/topographical models. Flood mapping is done with pre and post floods remote sensing datasets. For pre-Flood analysis, Normalized Difference Water Index (NDWI) map was prepared on Google Earth Engine (GEE), using Sentinel-2 images for the period of Feb. 2017 to identify permanent water bodies. For post-Flood analysis, GEE was used to download the pre-processed and thermal noise removed Sentinel-1 SAR image for Aug. 9, 2018, Aug. 14 and Aug. 21, 2018 and flood maps were generated using this data. In addition to SAR data, probable flood inundation areas using topography-based flood inundation tool HAND (Height Above Nearest Drainage tool) was also utilized. Hydrological simulation was carried out for all 12 major river sub-basins of Kerala, where floods are reported. Indian Meteorological Department-Global Precipitation Measurement (IMD-GPM) gridded daily data is used as input meteorological data for hydrological simulations. The hydrological simulations results were verified using published Central Water Commission (CWC) reports and reservoirs data for India-WRIS. The hydrodynamic simulation was also performed for simulating the Idukki dam release data and flood condition in downstream areas. Overall, an integrated study and developed approach can be utilized by state and central water and disaster management agencies to develop flood early warning systems.
\end{abstract}

\section{INTRODUCTION AND OBJECTIVES}

\subsection{Introduction}

Flood is one of the devastating natural calamities due to extreme rainfall events that affect the society (Mishra et al., 2018). Odisha flood (2006), Bihar flood (2008), Leh flash flood (2010), Assam flood (2012 and 2013), Kedarnath flash flood (2013) and Kashmir flood (2014) are the examples of devastated flooding events in the recent past years (Bhatt et al., 2017; Vishnu et al., 2019). The use of geospatial data, tools and hydrological models has become essential part of flood studies world over in the last 30 years (Liu and De Smedt, 2005; Aggarwal et al., 2009; Dang and Kumar 2017). The months of July-August, 2018 have seen heavy rainfall in the state of Kerala, India (CWC, 2018; Kerala State Disaster Management, 2018; Mishra et al., 2018; Vishnu et al., 2019) that caused worst flooded situations in the various regions of this state. The major rainfall events occurred at the end of July, 8-10 August and one extreme rainfall event occurred during 14-17 August 2018 (Table 1 showing total rainfall during 1 June -22 August 2018). Figure 1 shows the results of heavy rainfall that induced the floods in Kerala during August, 2018. The excess rain of July end and first week of August led to filling of most of the reservoirs and also saturating the soil, filling of drains, low laying areas to its full capacity. This situation was aggravated by very heavy rainfall during 15-17 August 2018, during which Kerala state received more than $250 \mathrm{~mm}$ of rainfall, and as per
IMD the total rainfall during 16-22 August was $302.7 \mathrm{~mm}$ as compared to normal rainfall of $94.7 \mathrm{~mm}$, with excess of $220 \%$. This led to opening of all major dams in upstream catchments of Kerala and out of total 58 dams, 35 were opened for the first time in the recent period (CWC, 2018).

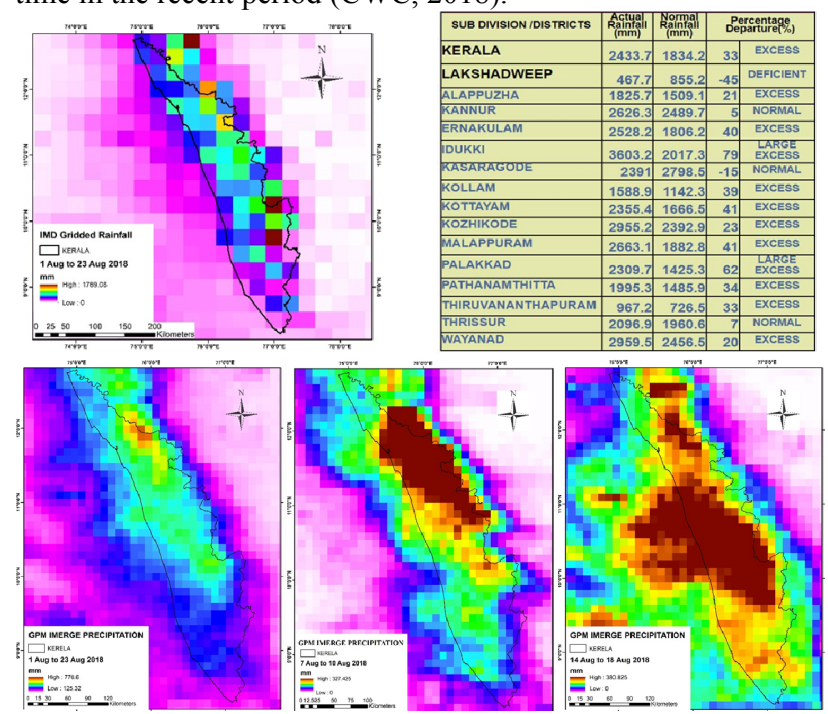

Figure 1. Seasonal Rainfall (in $\mathrm{mm}$ ) totals in Kerala from 01 June to 22 Aug 2018 (Source: IMD and NASA-GPM). Table 1: Total rainfall data from 1 June -22 August 2018 obtained from meteorological Centre, Thiruvananthapuram.

* Corresponding author 
The major causes of flooding, flood persistence and more flood damages in areas such as Alappuzha and Thrissur were as follows. Low elevation of terrain, location of these areas at lowest or outlet position of their catchments areas, lesser design capacity of Thottappally spillway and Thanneermukkom barrage, decrease in carrying capacity of Vembanad lake, very short distance from catchment ridgelines, less time of concentration and land use change from wetland, fallow to agriculture and human settlements. The IMD has forecasted very heavy rainfall in Kerala during 2 and $3^{\text {rd }}$ week of August, 2018, but due to lack of emergency operational plans for most of catchments and reservoirs, preventive action could not be taken. Therefore, the present study is under taken to study some of the hydrological consequences of such heavy rainfall using remote sensing data and hydrological modeling tools.

\subsection{Objectives}

The major objectives of current research is integrated study of Kerala floods, 2018 using the various geo-spatial data, meteorological data and hydrological models. The detailed study is done for all river basins of Kerala (Fig. 2), with GIS related information about for the two major river basins of Kerala viz. Periyar and Muvattupuzha as an example, along with the mapping of flood footprints using the Remote Sensing based optical and SAR data during the Kerala flood, 2018.

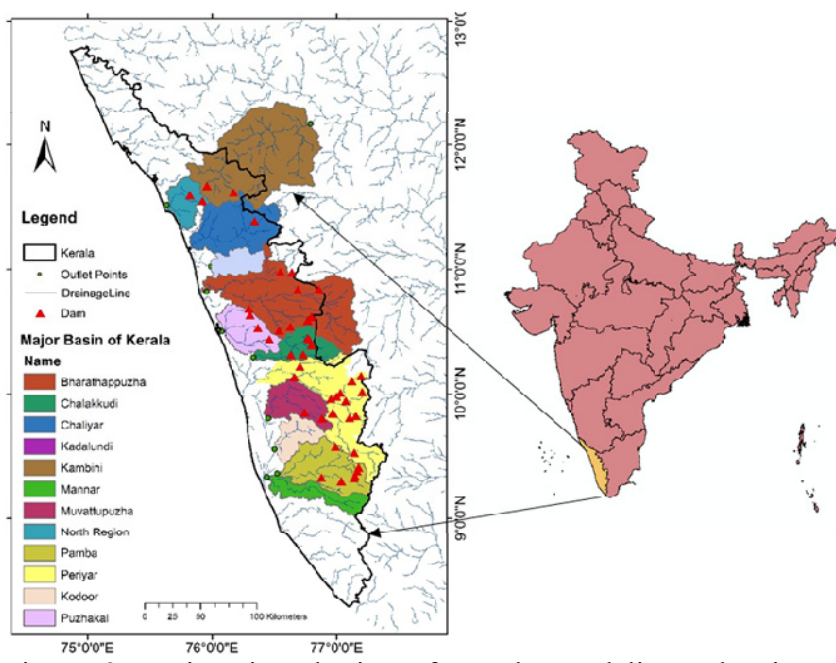

Figure 2. Major river basins of Kerala as delineated using ALOS-30 m DEM.

\section{MATERIAL AND METHODS}

\subsection{Study area}

The study area as shown in Figure 2 depicts the rivers basins of Kerala. It has a total geographical area of $38863 \mathrm{~km}^{2}, 14$ districts, with a North-South orientation and elongated shape. Kerala state has large number of rivers receiving the huge amount of rainfall every year (Kerala State Disaster Management, 2018). It has approximate length of $561 \mathrm{~km}$ and very short width of rivers approximately $100 \mathrm{~km}$, which gives a short time of travel for water to reach downstream areas from its farthest point at ridgeline. The elevation of Kerala ranges from $-48 \mathrm{~m}$ below sea level to $+2692 \mathrm{~m}$ above mean sea level, with $35 \%$ area between $0-50 \mathrm{~m}, 39.82 \%$ are between $50-500 \mathrm{~m}$ and $24 \%$ of area above $500 \mathrm{~m}$. The Southwest monsoon during the end of May or early June and the Northeast season (returning monsoon) during the mid-October are the two monsoonal pattern that is responsible for the two types of rainy seasons state namely, Edavapathi and Thulam respectively (Kerala State Disaster Management, 2018).

\subsection{Methods}

The overall methodology used in this work is shown in the figure $2 \mathrm{~b}$. In this work Arc-hydro based GeoHMS data model was used to integrate all the geospatial data to create the Kerala sub-basin physical maps and also as GIS pre-processor for hydrological modelling system (HMS). HMS hydrological model is chosen here as it is one of the most commonly used models in flood studies (Chu and Steinman, 2009; Unduche et al., 2018) The Digital Elevation Model (DEM) of $30 \mathrm{~m}$ spatial resolution was taken from ALOS (Takaku et al., 2016) to delineate watersheds. The minimum watershed area threshold for defining a stream was taken as $50 \mathrm{~km}^{2}$. The derived drainages and number of sub-watersheds are based on this threshold. The total drainage length and number of subwatersheds will increase if we decrease this threshold value. The HMS hydrological model was used for event based hydrological modelling and flood peak estimation with SCS loss method for initial abstractions (NRCS, 1986), SCS unit hydrograph for runoff transformation and Muskingum-cunge for river routing.

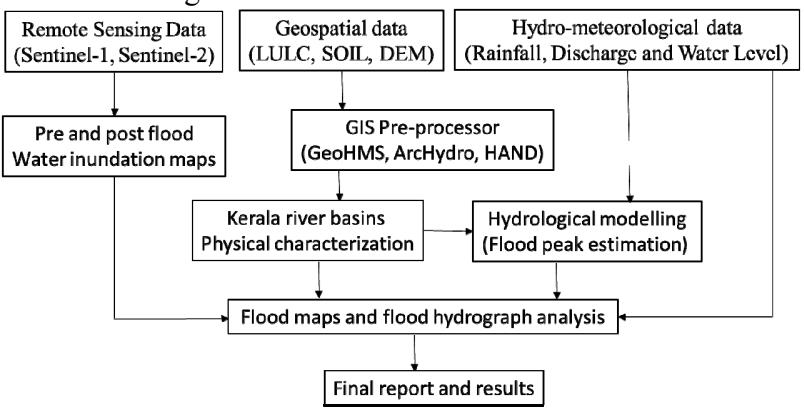

Figure 3. Overall methodology used for integrated hydrological study of Kerala 2018 floods

The remote sensing data derived land use land cover (Roy et al., 2016) at 1: 50,000 scale along with National Bureau of Soil Survey and Land Utilization Planning (NBSSLUP) was used to compute the Curve Number $(\mathrm{CN})$, later used for the runoff simulation in the HMS model (Figure 3). The National Resources Conservation Services Curve Number (NRCS-CN) method was estimate the runoff (Subramanya, 2008; Soulis and Valiantzas, 2012). Figure 4 shows the Curve Number (CN) ranges from 52 to 100 for this area, with area under CN 52-64 as $(0.46 \%), 65-74$ as $(23.02 \%), 75-85$ as $(65.98 \%)$ and $>85$ as $(6.8 \%)$. The high curve number indicates high runoff potential and low CN number gives low runoff potential (USDA, 1993; Hawkins, 1975). The major Land Use and Land Cover (LULC) taken from (Roy et al., 2016) in Kerala is Plantation (22255 $\mathrm{km}^{2} 58.23 \%$ ), Deciduous and Evergreen Broad Leaf Forest $\left(7849 \mathrm{~km}^{2}, 20.5 \%\right)$, Cropland/Shrubland/Grassland $\left(4307 \mathrm{~km}^{2}\right.$, $11.27 \%$ ) and Waterbody/Urban/Others (3806.5 $\left.\mathrm{km}^{2}, 9.95 \%\right)$. The critical analysis of LULC shows that, the low laying areas of south east and north of Vembanad Lake has been used for crop land as well as built up areas. The number of reservoirs in the Kerala have increased many fond since independence, with total of 58 numbers as per India WRIS. The major soil type of Kerala is Clay/Clay skeletal (31963 km², 83.83\%), Loamy/Loamy skeletal $\left(5339.20 \mathrm{~km}^{2}, 14 \%\right)$, small fractions of soil sandy. This high area under clayey soils can result in high runoff potential during heavy rainfall in all major catchments of state. 

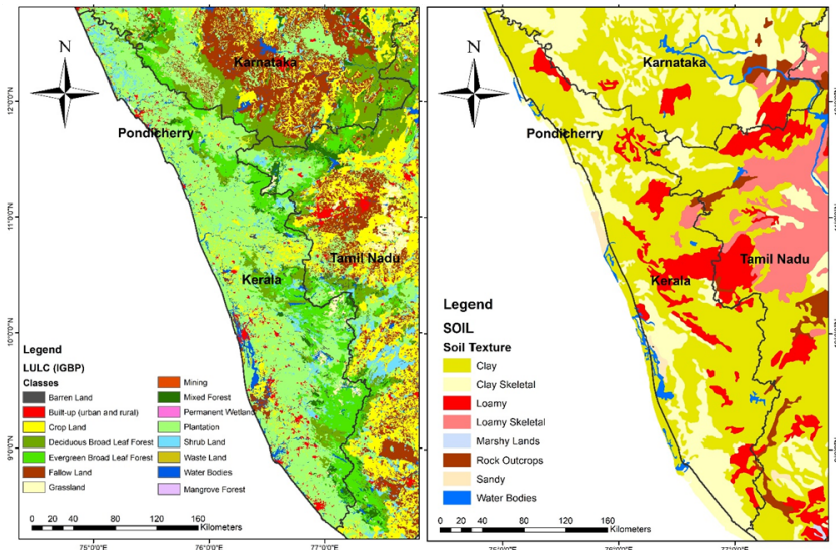

Figure 3. a) LULC map and b) Soil texture map of Kerala and surrounding areas.

The European Space Agencies (ESA's), Sentinel-1 synthetic aperture radar, SAR and Sentinel-2 multi-spectral imager, MSI sensor were used to map the flood waters.

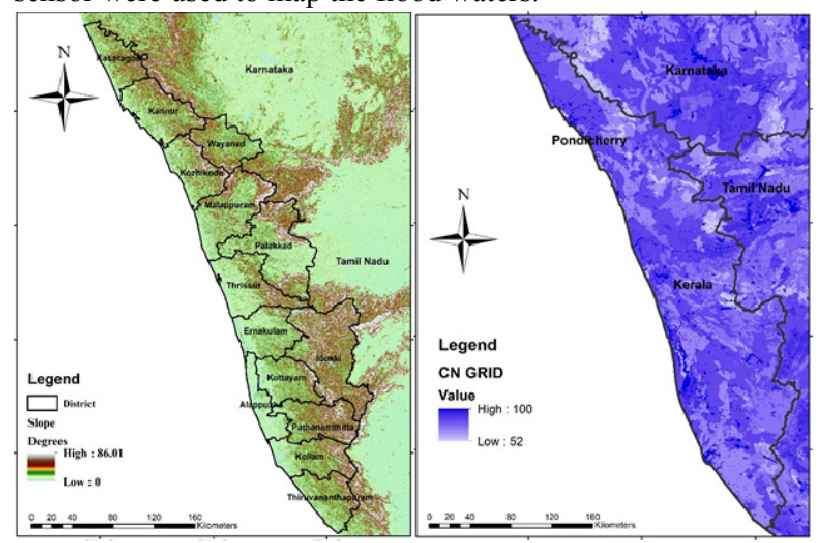

Figure 4. a) Slope, and b) Curve Number Grid map of Kerala

The detailed GIS based hydro pre-processing and hydrological modelling was done for all the river basin of Kerala. Periyar and Muvattupuzha basins with outlet at Alluva Manappuram Rail Bridge, Periyar Nagar and Vettikkattumukku Bridge using HMS model respectively (HEC, 2013) are shown in the Figure $5 \mathrm{a}$ as sample basins. Periyar basin has 47 sub-basins, with total area of $4276.9 \mathrm{~km}^{2}$ and $527.16 \mathrm{~km}$ drainage. Muvattupuzha basin has 15 sub-basins, with total area of $1560.7 \mathrm{~km}^{2}$ and $196.15 \mathrm{~km}$ drainage.

\section{RESULTS AND DISCUSSIONS}

The hydrological study is done for all the major river basin of Kerala (Table 2), but the detailed maps and hydrographs are shown for Periyar and Muvattupuzha basins as test basins. The Time of concentration (TC) was calculated for each subwatershed of each river basin with $50 \mathrm{~km}^{2}$ area threshold using the TR-55 method (NRCS, 1986). The actual time of travel for entire basin will be higher than the mean Tc.
Table 2: Area and drainage details of major flood affected

\begin{tabular}{|c|c|c|c|c|c|c|}
\hline S. No & Basin name & $\begin{array}{c}\text { Area } \\
\left(\mathbf{k m}^{2}\right)\end{array}$ & $\begin{array}{c}\text { Total } \\
\text { Drainage* } \\
(\mathbf{k m})\end{array}$ & $\begin{array}{c}\text { No. of sub- } \\
\text { watersheds* }\end{array}$ & $\begin{array}{c}\text { Mean Tc } \\
(\text { hours)*** }\end{array}$ & $\begin{array}{c}\text { No of major } \\
\text { dams/re servoirs }\end{array}$ \\
\hline 1 & Periyar & 4276.91 & 527.16 & 47 & 6.92 & 12 \\
\hline 2 & Pamba & 2486.7 & 320.37 & 17 & 12.14 & 4 \\
\hline 3 & North Region & 1008.4 & 114.73 & 11 & 11.21 & 2 \\
\hline 4 & Muvattupuzha & 1560.7 & 196.15 & 15 & 13.35 & 2 \\
\hline 5 & Mannar & 1234 & 155.83 & 7 & 20.48 & 0 \\
\hline 6 & Kambini & 6853 & 834.87 & 89 & 9.75 & 5 \\
\hline 7 & Kadalundi & 886.79 & 109.5 & 8 & 14.54 & 0 \\
\hline 8 & Chaliyar & 2915.73 & 329.93 & 37 & 7.16 & 1 \\
\hline 9 & Chalakudy & 1309.84 & 187.04 & 15 & 5.94 & 4 \\
\hline 10 & Bharathapuzha & 5884.24 & 782.92 & 73 & 9.88 & 6 \\
\hline 11 & Kodoor & 1045.28 & 107.15 & 14 & 10.69 & 0 \\
\hline 12 & Puzhakal & 1523.473 & 176.7 & 19 & 12.4 & 3 \\
\hline
\end{tabular}

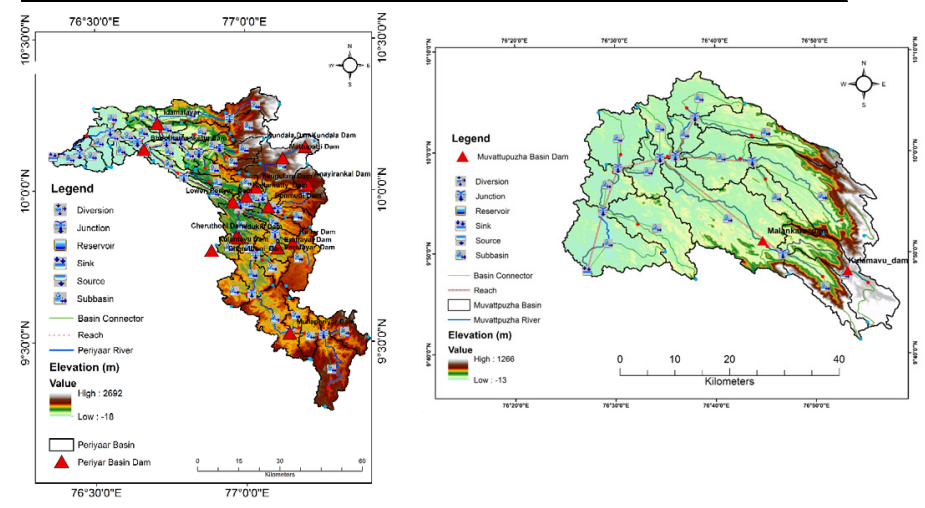

Figure 5. HMS model setup of a) Periyar River and b)

Muvattupuzha River basins derived from HEC-GeoHMS.

\subsection{Hydrological simulations for flood hydrograph generation}

The total mean rainfall for Periyar basin from 3-23 Aug 2018 was $945 \mathrm{~mm}$ with range from 132 to $1741 \mathrm{~mm}$. The HMS model was simulated from 03-23 Aug 2018 using this data, and model sate was saved till 23 August 201800 hours. Figure 7 shows the total flows along with flows coming from catchments of dams such as Idukki, Kallar, Lower Periyar, Kallarkutty, Kandalar, Eratayar, Ponmudi, Anayirankal, Sengulum, Bhoothathanketu, Mullaperiyar and Idamalayar dams.

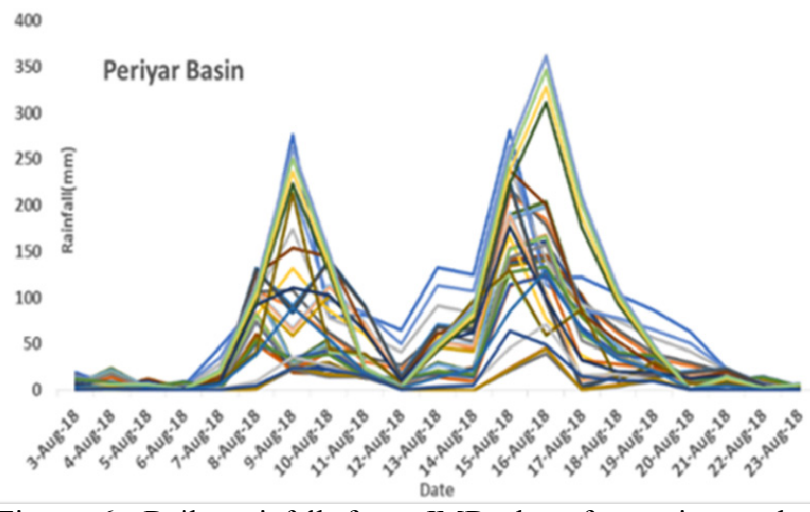

Figure 6. Daily rainfall from IMD data for various subwatersheds of Periyar river basin. 


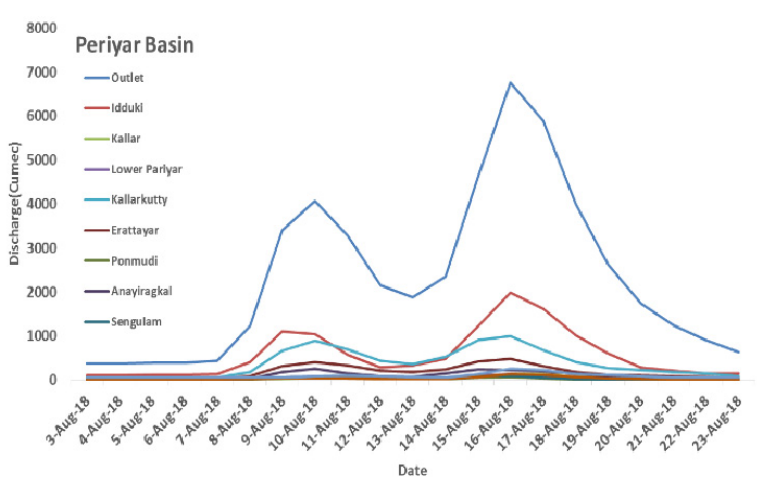

Figure 7. Daily flow obtained from HEC-HMS for outlets and major dams of Periyar river basin.

The maximum inflow obtained by watershed-based simulation at major dams such as Idukki, Kallarkutty, Eratayar, Kandala, Edamalayar, Anayirangal and Mullaperiyar were 1985, 1000, $483,483,261$ and 256 cumec respectively and the maximum outflow at the outlet was obtained 6761 cumec. The current simulations will be improved by incorporating the various major Dams and their outflows, to capture more details of actual flood scenarios. The characteristics of dams in Periyar basin are given in table 3 .

Flood hydrographs and sub-basin maps of Northern Kerala river basins, which were affected $1^{\text {st }}$ wave of floods in $1^{\text {st }}$ week of August 2018 are shown in appendix figure 14 (a, b and c) and $15(\mathrm{a}, \mathrm{b}$ and $\mathrm{c})$.

Table 3: Dams** in Periyar river basin and their characteristics

\begin{tabular}{|c|c|c|c|c|c|c|c|}
\hline Name & 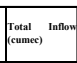 & \begin{tabular}{|l|}
$\begin{array}{l}\text { Maximum } \\
\text { intaum } \\
\text { (cumec) }\end{array}$ \\
\end{tabular} & River & $\begin{array}{l}\text { Total Volume } \\
\text { Conter of } \\
\text { Dam (TCM) }\end{array}$ & $\begin{array}{l}\text { Spillluy } \\
\text { caparity } \\
\text { (Camece) }\end{array}$ & $\begin{array}{l}\text { Na. of Spillway } \\
\text { Gates }\end{array}$ & Size of Spillway Gates $(\mathbf{m} \times \mathbf{m})$ \\
\hline Cheruthoni & 12120.9 & 1985.8 & Periyar & 467.29 & 750 & 5 & $12.19 \times 10.36$ \\
\hline Kallar & 964.8 & 134.3 & Kallar & 4 & $\mathrm{NA}$ & 4 & $7.62 \times 6.09$ \\
\hline Lower Pariyar & 912.9 & 136.2 & Periyar & 54 & 14200 & 7 & 5 Uppervent, 2 Lowervent \\
\hline Kallarkutty & 8019.4 & 1000 & Mudira Puzha & 40 & 1982.4 & 5 & $1 \times 0.533$ \\
\hline Idamalayar & 2204.4 & 342.6 & Idamalayar & 880 & 3012.8 & 4 & NA \\
\hline Kandala / Mattupatti & 3779.1 & 483.1 & Palar & 155 & 453.07 & 3 & $6.7056 \times 4.8768$ \\
\hline Eratayar & 3779.1 & 483.1 & Irattayar & 16 & 507 & 3 & $7.62 \times 6.09$ \\
\hline Ponmudi & 495.6 & 70.1 & Panniar & 181 & 1416.03 & 3 & $10.9728 \times 6.4008$ \\
\hline Anayirangal & 2035 & 261.3 & Panniar & 462 & 348 & & NA \\
\hline Sengulam & 743.4 & 106.5 & Mudriapuzha & 18 & 70.8 & $\mathrm{NA}$ & NA \\
\hline Bhoothathankettu & 733.9 & 128.6 & Periyar & $\mathrm{NA}$ & NA & 15 & $3 \mathrm{NO}-9.14 \times 10.36,12 \mathrm{No}$ \\
\hline Mullaperiyar & 1961.2 & 256.6 & Periyar & 443230 & 3454.62 & 13 & NA \\
\hline
\end{tabular}

**Idduki and Cheruthoni Dam both come under same sub basin hence in our study combined inflow of both is found.

The situation of water level in Idukki, Edamalayar and Periyar (Mullaperiyar dam) reservoirs of Periyar basin (India-WRIS) during Kerala flood was shown in the Figure 8 ( $a, b$ and $c)$. The simulated inflows for the Idukki, Edamalayar and Periyar reservoirs from the model (Figure 7) on August 08, 2018 were satisfactory matched with the actual inflows (Figure $8 \mathrm{a}, \mathrm{b}$, and c) (CWC, 2018).

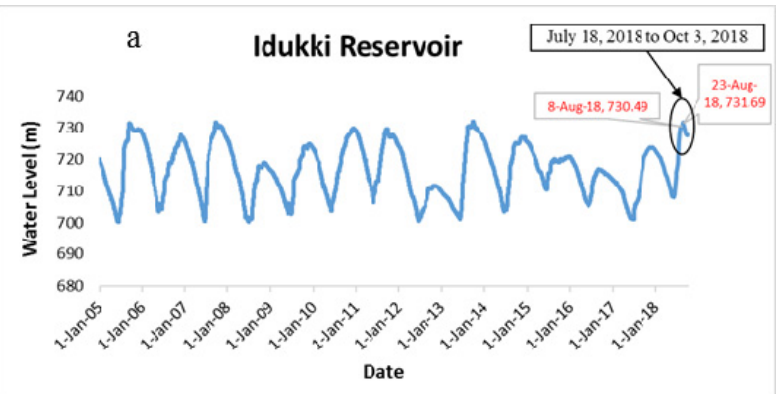

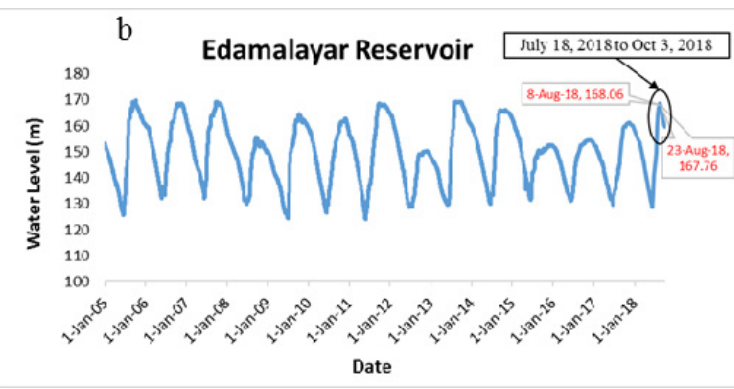

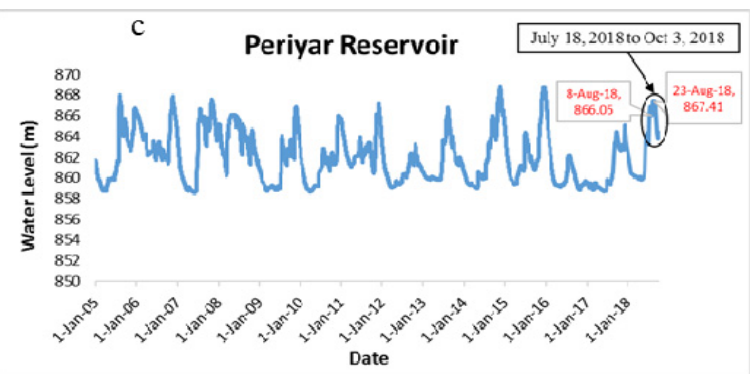

Figure 8 a). The variation of water level in Idukki reservoir from 2005-2018. The FRL of Idukki reservoir is $732.43 \mathrm{~m}$. And, water level during Kerala flood 2018 as on Aug 8 and Aug 23 were $730.49 \mathrm{~m}$ and $731.69 \mathrm{~m}$ respectively.

Figure 8 b). The variation of water level in Edamalayar reservoir from 2005-2018. The FRL of Edamalayar reservoir is 169.00 m. And, water level during Kerala flood 2018 as on Aug 8 and Aug 23 were $168.06 \mathrm{~m}$ and $167.76 \mathrm{~m}$ respectively.

Figure $8 \mathrm{c}$ ). The variation of water level in Periyar reservoir from 2005-2018. The FRL of Periyar reservoir is $867.41 \mathrm{~m}$. And, water level during Kerala flood 2018 as on Aug 8 and Aug 23 were $866.05 \mathrm{~m}$ and $867.41 \mathrm{~m}$ respectively.

The total mean rainfall for Muvattupuzha basin from 3-23 Aug 2018 was $638 \mathrm{~mm}$ with range from $471 \mathrm{~mm}$ to $1188 \mathrm{~mm}$. The HMS model was simulated from 03-23 Aug 2018 using this data, and model sate was saved till 23 August 201800 hours. Figure 10 shows the total flows along with flows coming from catchments of dams Kulamavu and Malankara.

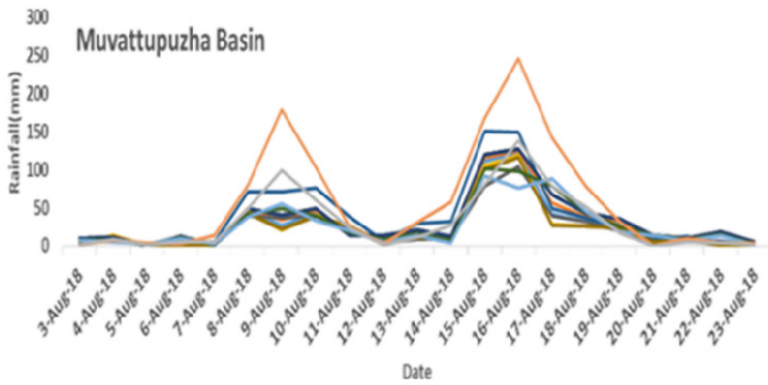

Figure 9. Daily rainfall from IMD data for various subwatersheds of Muvattupuzha basin.

In-direct comparison between simulated dam catchment flows (figure 7) and observed water levels (figure 8) revealed that there water level was at maximum levels during the flood peak occurrence as well as it remained high after few days from peak flood events due to sustained flows from upstream catchments. It should be noted that, as this study has not used reservoir release, the simulated peak flow $(6761$ cumec) were less than the actual observed peak flow (8800 cumec) at Neeleswaram outlet site for Periyar basin (CWC-2018). The simulated peak flows for Bharathapuzha basin were higher than the observed flows. In other sub-basins of Kerala, under estimation of simulated flows was observed as compared with CWC data. 


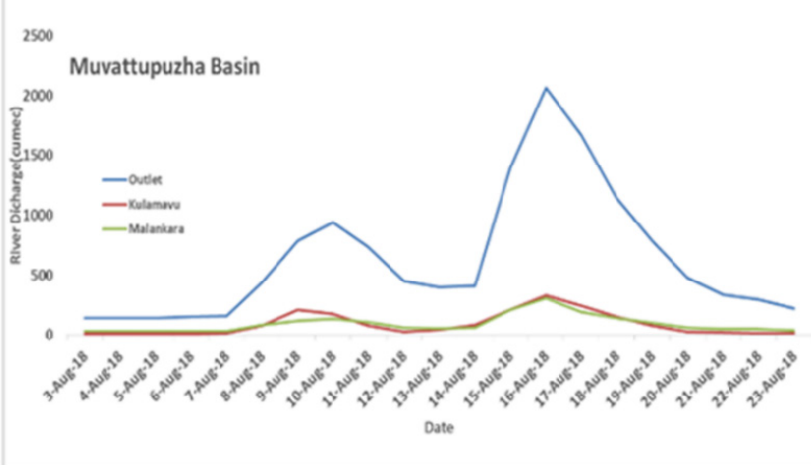

Figure 10. Daily flow obtained from HEC-HMS for outlets and major dams of Muvattupuzha basin

Table 3: Dams in Muvattupuzha basin and their characteristics

\begin{tabular}{|c|c|c|c|c|c|c|c|c|c|}
\hline Name & $\begin{array}{l}\text { Total } \\
\text { Inflow } \\
\text { (cumec) }\end{array}$ & $\begin{array}{l}\text { Maximum } \\
\text { Inflow }\end{array}$ & River & \begin{tabular}{|c|} 
Total \\
Volume \\
content \\
of Dam \\
(TCM) \\
\end{tabular} & \begin{tabular}{|c} 
Dessgn \\
Flood \\
(aumec)
\end{tabular} & \begin{tabular}{|c} 
Crest \\
Level of \\
Spplliway \\
(m)
\end{tabular} & $\begin{array}{l}\text { Solllway } \\
\text { Capacty } \\
\text { (cumec) }\end{array}$ & $\begin{array}{l}\text { No. of } \\
\text { Sppllway } \\
\text { Gates }\end{array}$ & $\begin{array}{c}\text { S1ze of } \\
\text { Spill way } \\
\text { Gates }(\mathrm{m} \\
\mathrm{x} \mathrm{m})\end{array}$ \\
\hline Kulamavu Dam & 1872.6 & 328.2 & \begin{tabular}{|l|} 
Kilivillithode \\
\end{tabular} & $\mathrm{Na}$ & $\mathrm{Na}$ & $\mathrm{Na}$ & $\mathrm{Na}$ & $\mathrm{Na}$ & $\mathrm{Na}$ \\
\hline Malankara Dam & 1961.8 & 305.4 & Thodupuzha & 46 & 1444.32 & 36.9 & 1444.32 & 6 & $7.6 \times 6$ \\
\hline
\end{tabular}

The maximum inflow obtained by watershed based simulation at Kulamavu and Malankara dams were 328 and 305 cumec respectively. The maximum discharge at the outlet was calculated as 2063 cumec. The current simulations can be improved by incorporating the various major Dams and their outflows, to capture more details of actual flood scenarios.

The simulated flood hydrographs matched well with that of CWC observed flow data (CWC, 2018), with some over or under estimation is our flood peaks, mainly due to the difference in input rainfall data and non-availability of actual reservoir outflow rates.

In addition, the water level data from India WRIS was also analyzed to confirm the change in the reservoirs water level during this flood events of 2018 (Figure $8 \mathrm{a}, \mathrm{b}$ and c). On 8th Aug and 23rd Aug, the water level in the Idukki reservoir was just $1.94 \mathrm{~m}$ and $0.74 \mathrm{~m}$ below from the FRL as shown in the fig 8a. The condition of water in Periyar Reservoir (Mullaperiyar dam) on 8th Aug is $1.36 \mathrm{~m}$ below from the FRL but on 23th August reservoir was filled upto $867.41 \mathrm{~m}$, which is equal to its maximum capacity, shown in the figure 8c. This signifies impact of two major consecutive very heavy rainfall event spaced within 5 days, amplified the flood problem in downstream areas.

\subsection{Flood Inundation mapping}

The flood mapping was also carried out using combination of radar data from Sentinel-1 SAR data, cloud free optical Sentinel-2 data and also with topography based indices (Figure 11 and 12).

For pre-Flood analysis, NDWI map was prepared on Google Earth Engine (GEE), using Sentinel-2 images for the period of Feb. 2017 merged with Sentinel-2 image for the period of Feb. 2018 , using threshold of 0 , to identify permanent water bodies. For post-Flood analysis, GEE was used to download the preprocessed and thermal noise removed Sentinel -1 image for Aug. 9, 2018, Aug. 14 and Aug. 21, 2018. Firstly, the Sentinel1 image for Aug. 9, 2018 was processed on GIS software. For identifying flood pixels, a threshold value of $-14 \mathrm{~dB}$ is adopted.
The image was then reclassified into water and non-water as 2 and 0 respectively. Then, using NDWI map, the water and nonwater pixels were classified as 1 and 0 respectively. Final Flood map was prepared by adding images of Sentinel 1 and NDWI, and finally assigning value to Flood pixels as 1, permanent water bodies as 0 and 2, as shown in Figure 11 a. The inundated area was computed to be $702 \mathrm{~km}^{2}$.

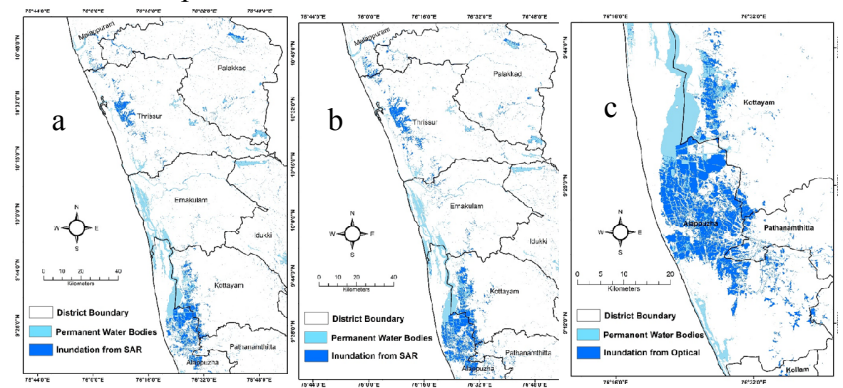

Figure $11 \mathrm{a}, \mathrm{b}$ and $\mathrm{c}$. Flood inundation map obtained from remote sensing data (SAR and cloud free optical data of Sentinel-1, 2).

Similar approach was adopted for the Sentinel-1 image for Aug. 21, 2018 to prepare final flood inundation map, as shown in Figure $11 \mathrm{~b}$. The inundated area was calculated as $905 \mathrm{~km}^{2}$. Also, using Sentinel 2 image acquired on Aug. 22, 2018, NDWI map was prepared using Green and NIR band of this image on GIS software. A threshold of 0 was given to identify water pixel. Thus, a final flood map as shown in Figure $11 \mathrm{c}$, was prepared by adopting the same methodology as discussed before. The inundated area captured from single tile of Sentinel 2 image comes out to be $379 \mathrm{~km}^{2}$. Attempt has been made to capture probable flood inundation areas using topography-based flood inundation tool HAND (Height Above Nearest Drainage tool) (Liu et al., 2016), with DEM from ALOS $30 \mathrm{~m}$ data (Takaku et al., 2016). Thresholding (ranging between 0 to 12 m) was given with respect to Kodoor and Pamba basins topography, results showed good match at middle and downstream area of the respective basins, while over/under estimated for some parts of the upstream/other/lower basin areas (Figure 12). The flood inundation from HAND tool can be improved by better DEM and multiple/variable thresholds for various streams. It is to be noted that the SAR data Based flood gives low flooded area as it is taken 3 days after peak flood.

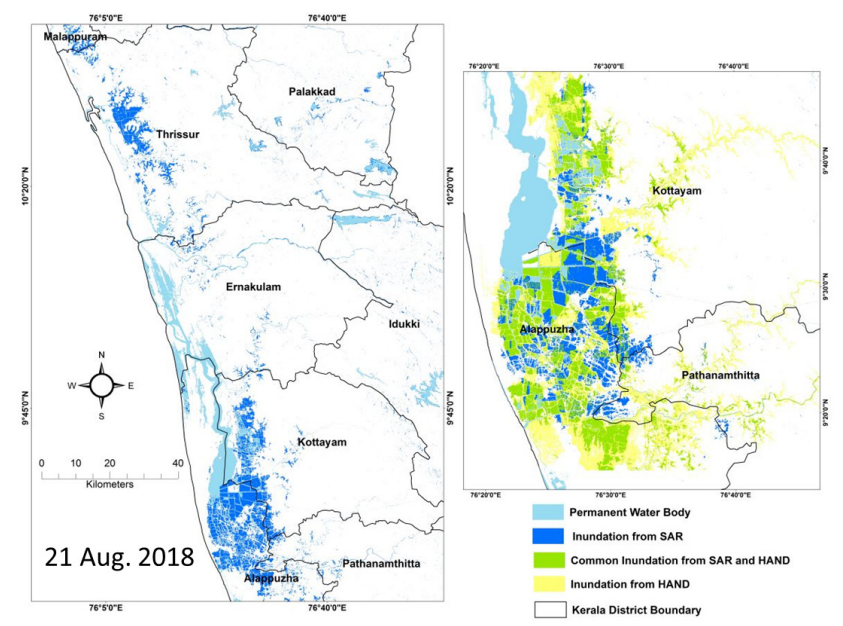

Figure 12. SAR based \& ALOS- $30 \mathrm{~m}$ DEM + HAND based flood inundation maps for Kerala. 


\subsection{Hydrodynamic modeling of Idukki dam}

The hydrodynamic simulation was also performed for simulating the Idukki dam release data and flood condition in downstream areas using mike 11,1 dimensional (1-D) hydrodynamic model (HD). The river channel and other topographical data was taken from ALOS 30 DEM and as all 5 gates of Idukki dam were opened, the discharge data of 770 cumec was used for simulation. The 1D HD model was established for a Periyar river reach of $17.5 \mathrm{~km}$ with upstream end at Cheruthoni dam. Figure 13 shows the flood inundation at downstream area of Cheruthoni dam. The close view of flood inundation just downstream of Idukki dam is shown figure 16 of appendix.

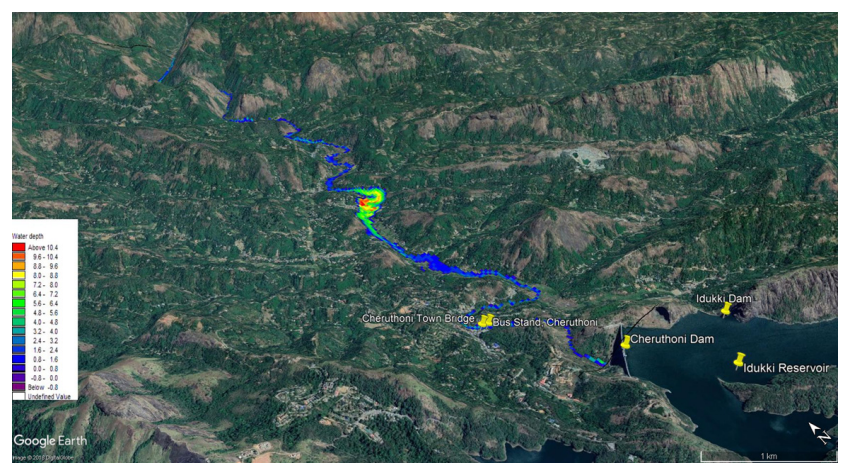

Figure 13 Simulated flood inundation in Periyar River at downstream area of Cheruthoni dam.

\section{CONCLUSIONS \& RECOMMENDATIONS}

Kerala received actual rainfall of $2394.1 \mathrm{~mm}$ from June 1 to Aug 22, 2018, which exceeds normal rainfall of $1701.4 \mathrm{~mm}$ by $41 \%$ (IMD) as per IMDs rainfall products of IMD-GPM at 0.25 degree, which combines rain gauge data with GPM data. The rainfall data analysis also showed that entire Kerala had received more than normal rainfall till 7 August 2018, which caused filling of many of the reservoirs. This heavy rainfall resulted in high surface runoff in major river basins of Kerala, filling of all dams and subsequent opening of these dams, caused widespread flooding in downstream areas, low lying areas near coast and backwaters of Kerala. As this study has used gridded IMD-GPM data and without actual reservoir operations, future improvements simulated studies can be done by incorporating the actual rain gauge, reservoirs operations and observed flow data at various locations to improve calibration/validation of hydrological models results.

The hydrological modelling of major 12 river basins showed that due to heavy rainfall during Aug 07-10 and Aug 14-18, 2018, most of the sub-catchments produced heavy surface runoff, mainly due to clay soil, and in some areas, steep slope and urbanization, which resulted in flood flows ranging from 50 to 400 cumec from each sub-watersheds. The dams acted as buffer for excess water upto 7 August 2018, but after that during two very heavy rainfall spells of 2 and $3 \mathrm{rd}$ week of August 2018, subsequent very heavy in-flows into the reservoirs, and opening of the all spillway gates of these full dams, caused heavy flood flows in downstream areas.

In future, proper formulation of emergency standard operating procedures in consultation with state and central government agencies such as central water commission (CWC) need to be setup to minimize such major flood related disasters. The implementation of combined weather, hydrological and flood inundation forecast is needed along with construction flood shelters at suitable high grounds in all flood prone areas of state, to minimize impact of any such disaster in future

\section{Acknowledgements}

The authors acknowledges constant support and encouragement of Director, Indian Institute of Remote Sensing (IIRS) and Group Head, Water Resources Department (WRD) for initiation, completion and reporting of this work in such short time period. The technical support provided by faculty and students of WRD is also appreciated. The SRTM $30 \mathrm{~m}$ DEM data was available from the U.S. Geological Survey. Sentinel-1 SAR and Sentinel-2 optical data was provided by ESA Copernicus.

\section{References}

Aggarwal, S.P., Thakur, P.K. and Dadhwal, V.K., 2009. Remote sensing and GIS applications in flood management. Journal of Hydrological Research and Development, Theme Flood Management, 24, 145-158.

Bhatt, C.M., Rao, G.S., Farooq, M., Manjusree, P., Shukla, A., Sharma, S.V.S.P., Kulkarni, S.S., Begum, A., Bhanumurthy, V., Diwakar, P.G., Dadhwal, V.K., Rao, G.S., Farooq, M., Manjusree, P., and Shukla, A., 2017. Satellite-based assessment of the catastrophic Jhelum floods of September 2014, Jammu \& Kashmir, India. Geomatics, Natural Hazards and Risk, 8 (2), 309-327.

Central Water Commission (CWC), 2018. Study report Kerala floods of August 2018. 48 pages.

Chu, X. and Steinman, A., 2009. Event and continuous hydrologic modeling with HEC-HMS. Journal of Irrigation and Drainage Engineering-ASCE, 135 (1), 119-124.

Dang, A.T.N. and Kumar, L., 2017. Application of remote sensingand GIS-based hydrological modelling for flood risk analysis: a case study of District 8, Ho Chi Minh city, Vietnam. Geomatics, Natural Hazards and Risk, 8 (2), 1792-1811.

Hawkins, R.H. (1975). The importance of accurate curve numbers in the estimation of storm runoff. Water Resources Bulletin, 11(5), 887-891.

Hydrologic engineering Centre, HEC (2013). User's Manual, Hydrologic Modeling System HEC-HMS. US Army Corps of Engineers: Hydrologic Engineering Center, 10. CA, USA, CPD-74A.

India-Water Resources Information System, WRIS, 2018: www.india-wris.nrsc.gov.in accessed on September 10, 2018.

Liu, Y.B., and De Smedt, F., 2005. Flood Modeling for Complex Terrain Using GIS and Remote Sensed Information. Water Resour Manage 19, 605-624.

Liu, Y., Maidment, D., Tarboton, D., Zheng, X., Yıldırım, A., Sazib, N., Wang, S. A (2016). CyberGIS Approach to Generating High-Resolution Height Above Nearest Drainage (HAND) Raster for National Flood Mapping. In Proceedings of 
the Third International Conference on CyberGIS and Geospatial Data Science, Urbana, IL, USA, 26-28 July 2016.

Kerala State Disaster Management, 2018. ADDITIONAL MEMORANDUM Kerala Floods - 2018 1st August to 30th August 2018.

Mishra, V., Aaadhar, S., Shah, H., Kumar, R., Pattanaik, D.R., and Tiwari, A.D., 2018. The Kerala flood of 2018: combined impact of extreme rainfall and reservoir storage. Hydrology and Earth System Sciences Discussions, (September), 1-13.

Natural Resources Conservation Service, NRCS (1986). Urban Hydrology for Small Watersheds. Technical Release 55, US Department of Agriculture, Natural Resources Conservation Service (NRCS), 210-VI-TR-55, Second Ed., June 1986, 164 p.

Roy, P.S., P. Meiyappan, P.K. Joshi, M.P. Kale, V.K. Srivastav, S.K. Srivasatava, M.D. Behera, A. Roy, Y. Sharma, R.M. Ramachandran, P. Bhavani, A.K. Jain, and Y.V.N Krishnamurthy. 2016. Decadal Land Use and Land Cover Classifications across India, 1985, 1995, 2005. ORNL DAAC, Oak Ridge, Tennessee, USA. http://dx.doi.org/10.3334/ORNLDAAC/1336.

Saksena, S. and Merwade, V. (2015). Incorporating the effect of DEM resolution and accuracy for improved flood inundation mapping. J. Hydrol., 530, 180-194.

Subramanya, K. (2008). Engineering Hydrology. Tata McGrawHill Publishing Company Limited.

Soulis, K.X. and Valiantzas, J.D., 2012. SCS-CN parameter determination using rainfall-runoff data in heterogeneous watersheds - the two-CN system approach. Hydrol. Earth Syst. Sci., 16, pp. 1001-1015.

Thakur, P. K, Dhote, P., and 7 others (2018). Hydrological Study of August 2018 Kerala Floods using Remote Sensing, Hydrological Modelling and Geospatial tools. IIRS internal technical report, IIRS/WRD/Research/Kerala2018/v2.1/250, 47 pages.

Takaku, J., Tadono, T., Tsutsui, K. and Ichikawa, M. (2016). Validation of 'AW3D' Global DSM Generated from ALOS PRISM, ISPRS Annals of the Photogrammetry, Remote Sensing and Spatial Information Sciences, Vol.III-4, pp.25-31.

Takaku, J. and Tadono, T. Quality updates of 'AW3D' global DSM generated from ALOS PRISM. Proc. IGARSS2017, IEEE, Fort Worth, TX, USA., pp. 5666-5669, 2017. https://ieeexplore.ieee.org/document/8128293/

U.S. Department of Agriculture, Soil Conservation Service. (1993). National Engineering Handbook, Section 4, Hydrology (NEH-4).

Unduche, F., Tolossa, H., Senbeta, D. and Zhu, E., 2018. Evaluation of four hydrological models for operational flood forecasting in aCanadian Prairie watershed. Hydrological Sciences Journal, 63:8, 1133-1149.

Vishnu, C.L., Sajinkumar, K.S., Oommen, T., Coffman, R.A., Thrivikramji, K.P., Rani, V.R., and Keerthy, S., 2019. Satellitebased assessment of the August 2018 flood in parts of Kerala, India. Geomatics, Natural Hazards and Risk, 10 (1), 758-767.

\section{APPENDIX}

The Northern Kerala river basins such Kambini and Puzhakal also received heavy rainfall during 7-10 and 14-18 Aug. 2018, which resulted in many landslides in upper catchments of Kerala and Karnataka, flooding along river and major flood inundation in Wayanaad and Thrisoor areas. This appendix gives information and hydrological study data for those river basins.

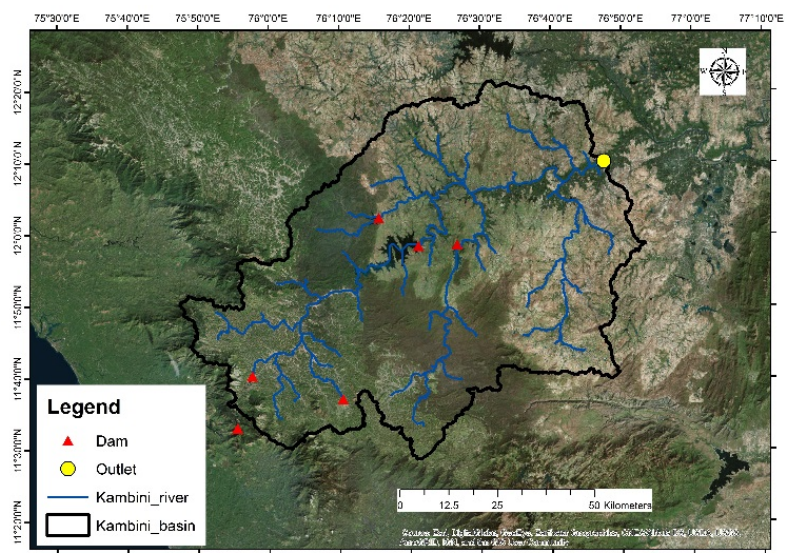

Figure 14a: Kambini River basin and its dam locations

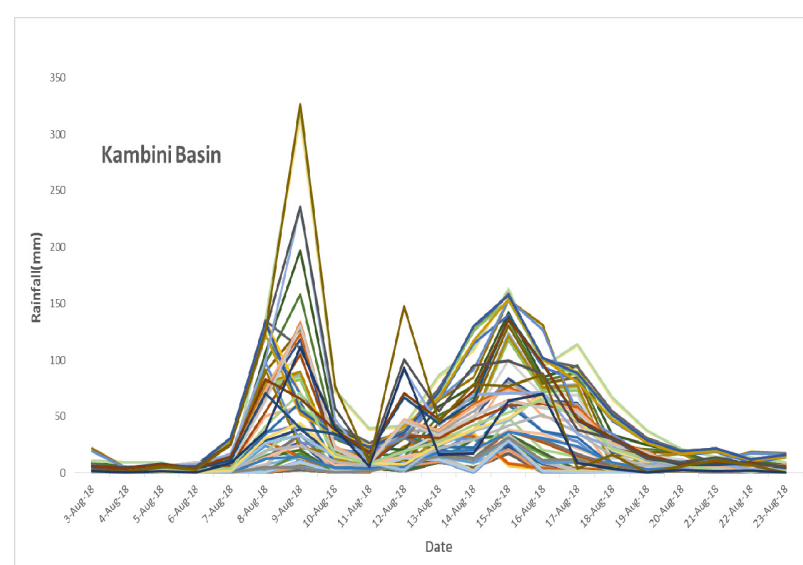

Figure 14b: Daily rainfall from IMD data for various subwatersheds of Kambini river basin.

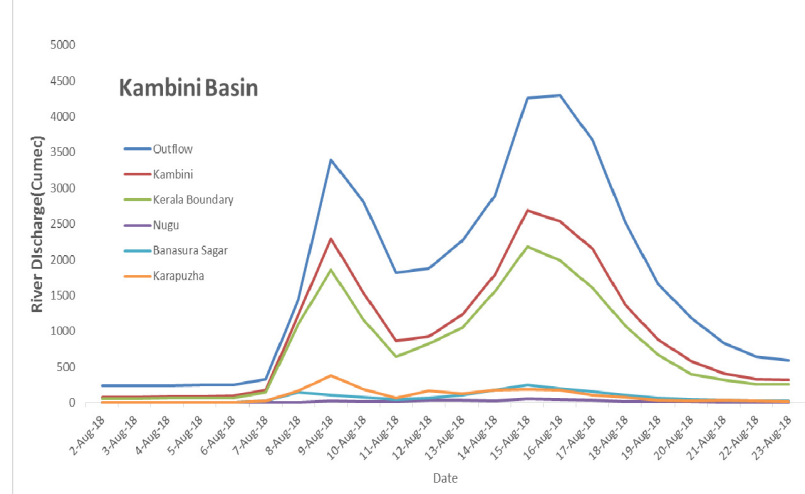

Figure 14c: Daily flow obtained from HEC-HMS for outlets and major dams of Kambini river basin. 


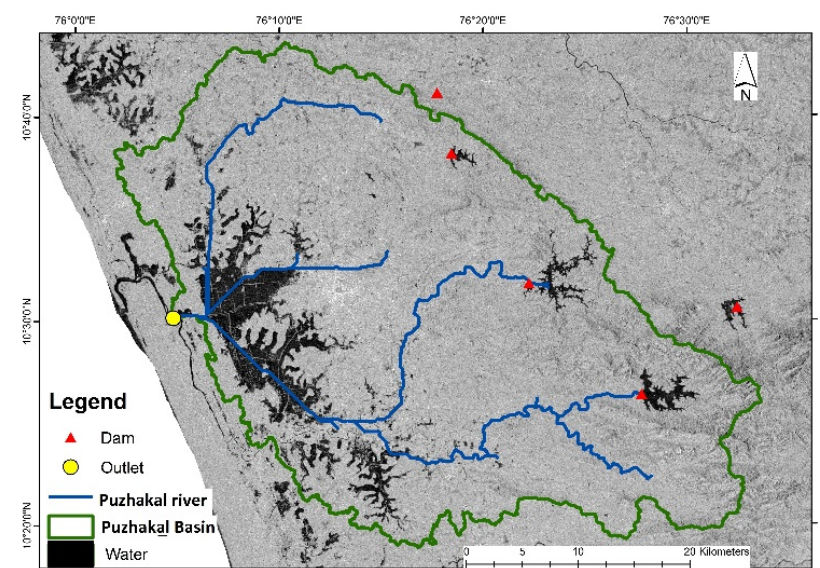

Figure 15a: Puzhakal River basin and its dam locations, the Sentinel-1 SAR data of flood time is given in background.

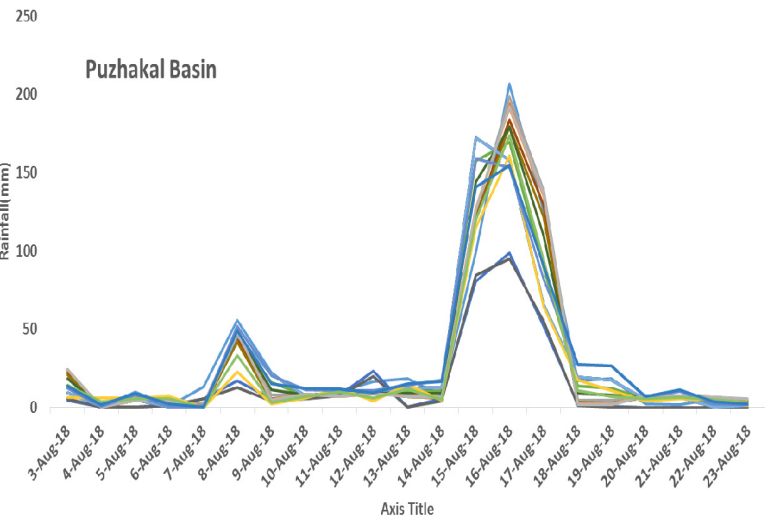

Figure 15c: Daily flow obtained from HEC-HMS for outlets and major dams of Puzhakal river basin.
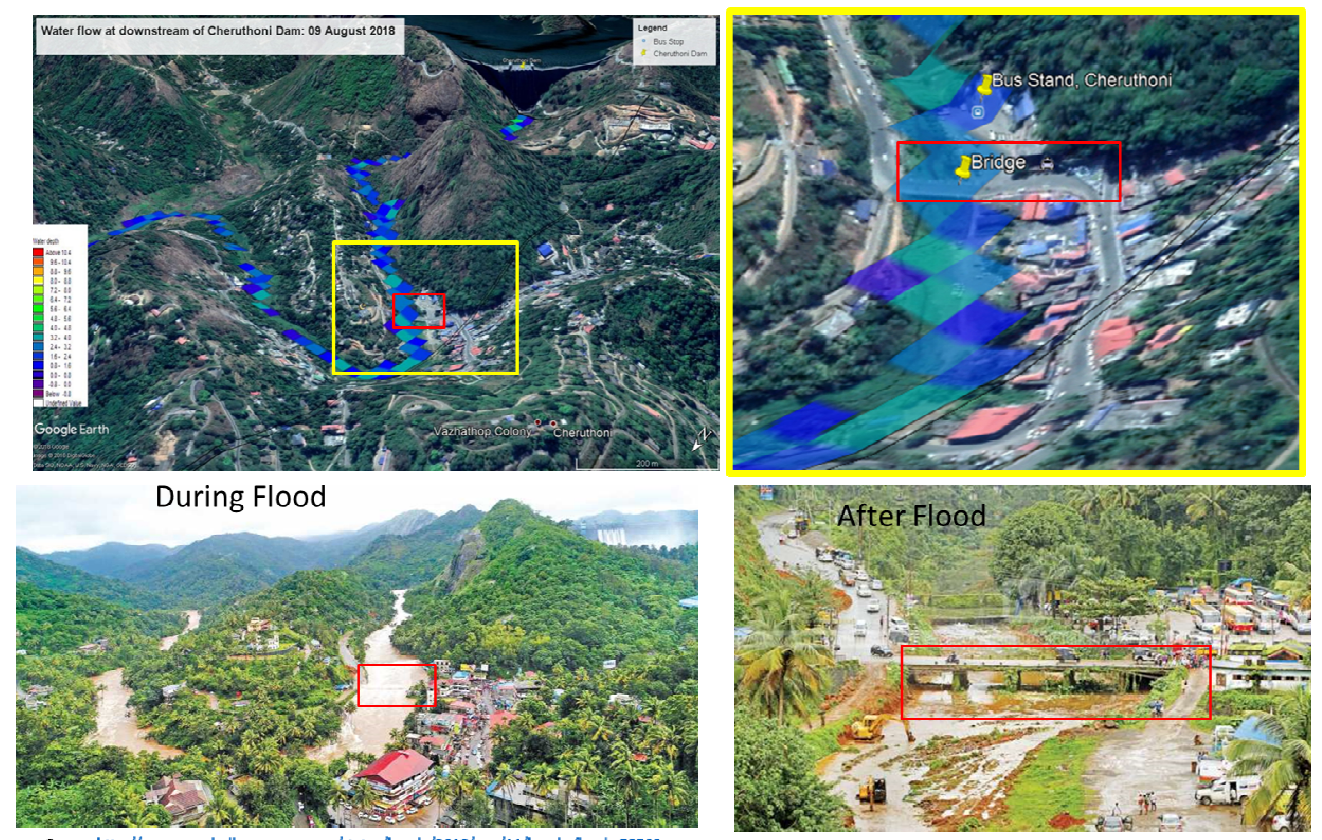

Source:http://wwws.newindlianexpress.com/states/kerala/2018/aug/11/kerala-floods-53500

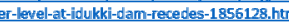

Figure 16. Flood inundation $\mathrm{d} / \mathrm{s}$ of Cheruthoni dam as simulated using 1D HD model and as observed in reality from field pictures from media.

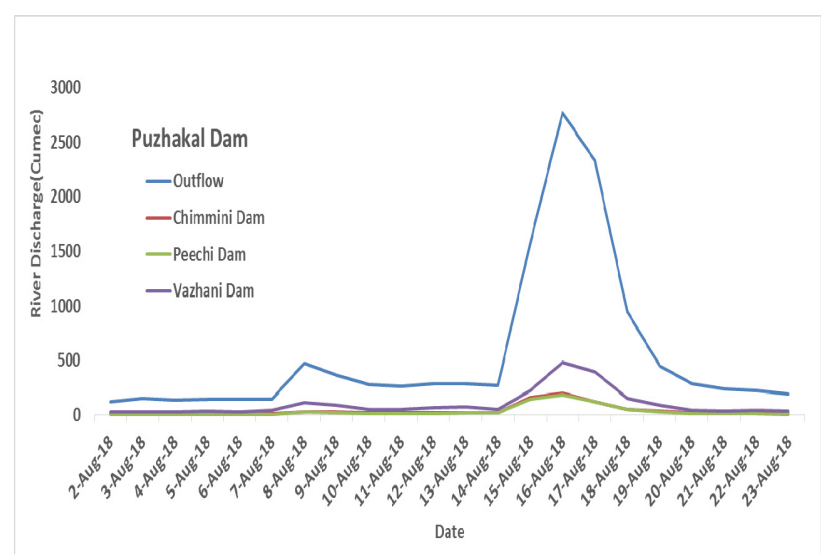

Figure 15b: Daily rainfall from IMD data for various subwatersheds of Puzhakal river basin. 